\title{
Social Personal Competence of Guidance and Counseling Teachers in Professional Development Program and the Implication for Guidance and Counseling
}

\author{
Setiawati \\ Educational Psychology and Guidance \\ Universitas Pendidikan Indonesia, Indonesia \\ atiesw@yahoo.com
}

\author{
Juntika Nurihsan \\ Educational Psychology and Guidance \\ Universitas Pendidikan Indonesia, Indonesia \\ juntikanurihsan@upi.edu
}

\author{
Nurnaifah Selvia Wardhani \\ Educational Psychology and Guidance \\ Universitas Pendidikan Indonesia, Indonesia \\ selviaward@student.upi.edu
}

\begin{abstract}
The research was motivated by the problem on Guidance and Counseling Teacher competence that does not reflect a sustainably ideal improvement that should be owned by Guidance and Counseling Teacher as a professional worker. Competence refers to the awareness of science and technology development as a form of dynamic active performance. This research was mainly based on the importance of competence understanding for Guidance and Counseling Teachers. This research aimed to derive an overview of the competence of Guidance and Counseling Teachers who attend Program Pendidikan Profesi Guru Dalam Jabatan in Indonesia University of Education Academic Year 2018/2019. This research utilized a quantitative approach with descriptive methods. The population and sample of this research were Guidance and Counseling Teachers who attend PPG-BK Program at UPI Academic Year 2018/2019 with 95 respondents. The data collection was carried out through social personal competence instruments based on Ministry of Education and Culture Regulation No. 27 of 2008. The results of the research revealed an overview of the social personal competence of Guidance and Counseling Teachers which are in competent category that means that they understand aspects of social personal competence well.
\end{abstract}

Keywords: competence, personal competence, social competence

\section{INTRODUCTION}

Guidance and counseling activities in school plays important role in an effort to develop students' potency optimally. In line with Fuad [1] that the guidance and counseling activity is basically a bilateral interaction, in which there is an interplay between the Guidance and Counseling Teacher as the assisting party and the counselee as the assisted party.

However, the challenges and problems of education recently are increasingly complex and heavily demand the role of Guidance and

Counseling Teacher to be more professional in working. As a professional worker, the Guidance and Counseling Teacher should have basic competencies to guide and optimize the counselee in achieving the potential development. Nevertheless, considering the Guidance and Counseling Teacher or counselor is assumed as the person who will guide the counselee in achieving particular goals, in this relationship then a Guidance and Counseling Teacher needs to have certain capacity [1]. This particular capacity is significant because it will determine the quality of the Guidance and Counseling Teacher [2].

The quality of Guidance and Counseling Teachers is assessed from their abilities and competencies in conducting guidance and counseling services. The meaning of competence is considered as the performance pillar of one profession or in this context is teachers' performance including Guidance and Counseling Teachers. The Competence of Guidance and Counseling Teacher involves pedagogical, personal, social and professional competencies that is collaborating as a wholeness. The performance of the Guidance and Counseling Teacher is extremely influenced by the mastery caliber of those four competencies which are based on attitudes, values, and supporting personal propensities. Academic competence and professional of Guidance and Counseling teacher in an integrated way builds the integrity of pedagogical, personal, social and professional competencies.

Guidance and Counseling teachers as individuals must be able to perform their identity fully, precisely, and means to build unique, harmonious, dynamic, persuasive and creative interpersonal relationships so that they become the driving force of the success of counseling and counseling services [3].

From a number of previous studies, Rofiqah [4] pedagogical, personal, social and professional competence of BK teachers in state high schools in Rejang Lebong Regency is in quite good achievement. In line with the research findings of Sisrianti, et al. [5] and Efendi, et al. [6] Personality competence of BK 
Teachers/Counselor in SMPN 5 Pariaman and social competence of BK Teachers/Counselor in SMA Negeri Padang overall are in the sufficient category. From the results of a preliminary research conducted by researcher on several BK teachers in SMA Negeri 20 Bandung, it is also known that some BK teachers still use skills that are based on experience and lack of participation in optimal guidance and counseling services. The fact in the field explains that BK teachers still get difficulty to make semester/annual programs based on the student's assessment needs.

According to Kamaluddin [7] the low quality of guidance and counseling services in schools is caused by several factors, namely the number of Guidance and Counseling Teachers in each school that is not in accordance with the ratio of 1: 150 students, Guidance and Counseling Teachers have not fully mastered and have competence as counselors, Guidance Teachers and Counseling generally does not master the knowledge that must be possessed by a counselor in accordance with Law Number 20 of 2003 Article 1 paragraph (6), and the Guidance and Counseling Teacher is still in multiple duties.

Various efforts had been made to support this so that Guidance and Counseling Teachers can improve their abilities even better such as the implementation of the Professional Education of Guidance and Counseling Teacher Program (PPG-BK) in order to obtain a certificate of professional education in early childhood education, basic education and intermediate education. This is regulated in Minister of Education and Culture Regulations No 87 of 2013 that the PPG Program is organized to prepare teachers to completely master teacher competence in line with national education standards. This program is conducted every year to support teachers' professionalism, especially the Guidance and Counseling Teacher in conducting their duties. Additionally, the principals undertake coaching effort related to the competence of BK teachers in schools. In fact, this coaching effort is still not effective in relation to competencies development that is still not maximum.

Ideally, guidance and counseling are the principal cores of professionalism which must always be developed as a teaching profession. Suherman [8] points out a new paradigm of counseling vision and mission supported by the constancy of professional organizations pillars and laws and regulations that is increasingly clear opening up opportunities for the counselor profession to always improve their quality in a sustainable manner and evolve in line with the abilities of the profession, and the needs, demands and expectations. This further strengthens that there is no other reason to improve the quality of Guidance and Counseling Teacher or counselor because of the support from various parties.

Therefore, Guidance and Counseling Teachers are expected to understand self- awareness as a form of personal actualization to be the basis to increase the competence of Guidance and Counseling Teachers in providing performance assessment of Guidance and Counseling Teachers in schools to create professional Guidance and Counseling Teachers [9]. Performance assessment of Guidance and Counseling teachers can also be seen based on working experience in the educational world which supports quality improvement based on the experience and qualifications of education personnel.

Referring to the existing problems, the problem statements of this research are stated in the following questions.

1. What is the personal competence profile of the Guidance and Counseling Teachers who attend Pendidikan Profesi Guru Dalam Jabatan Program in Indonesia University of Education Academic Year $2018 / 2019$ ?

2. What is the personal competence profile of the Guidance and Counseling Teachers who attend Pendidikan Profesi Guru Dalam Jabatan Program in Indonesia University of Education Academic Year 2018/2019 based on age, educational background, tenure, and the regional background?

3. What are the implications of social personal competence development service of the Guidance and Counseling Teachers who attend Pendidikan Profesi Guru Dalam Jabatan Program in Indonesia University of Education Academic Year 2018/2019?

Every research surely has certain objectives that lead to the desired results. This study aimed to answer the questions contained in the problem statements that were to find out the general description of the social personal competence of Guidance and Counseling Teachers who attend the Pendidikan Profesi Guru Dalam Jabatan Program in Indonesia University of Education Academic Year 2018/2019 as well as the description based on age, educational background, tenure, regional background, and compose a hypothetical design of improvement program for the competence of guidance and counseling teachers.

\section{METHOD}

This research utilized a quantitative approach with descriptive methods aimed to derive data in the form of numbers that would describe the social personal competence of Guidance and Counseling Teachers who attend the Program Pendidikan Profesi Guru Dalam Jabatan in Indonesia University of Education Academic Year 2018/2019. The participants of this research were the Guidance and Counseling Teachers who attend Pendidikan Profesi Guru Dalam Jabatan Program in Indonesia University of Education Academic Year 2018/2019. The research sample was taken using saturation sampling technique with 183 respondents.

The process of data collection was done by distributing the instruments of guidance and counseling teachers' competence. The instrument development was conducted by instrument's feasibility test to three experts, the readability test to the respondents who had similar characteristics to the participants, and the instrument trial. Based on the results of the instrument trial, there were 65 valid statement items. The validity test utilized the Rasch model application by looking at the score of Outfit Mean Square (MNSQ), Outfit Z-Standard (ZSTD), Point Measure Correlation (Pt Mean Corr), Undimensionality, and Rating Scale.

The Alpha Cronbach score was 0.84 which revealed the interaction between items and person was 
overall in a very good category so that it can be utilized as a data collection tool. The instrument development used a Likert scale with five alternative answers choices starting from Always (SL), Frequently (SR), Rarely (J), Ever (P) and Never (TP). It revealed a scale that theoretically has the same interval between each answer choice. In the instrument of guidance and counseling teachers' competence, if students on a statement answer "Always" it was given a score of 5, "Often" 4, "Sometimes" 3, "Ever" 2, "Never" 1 for positive statements, while for negative statements "Always" was given a score of 1 , "Often" 2, "Sometimes" 3, "Ever" 4, "Never" 5.

Data grouping was divided into five categories, namely; mastery, competent, threshold, flow, and beginner. The score of guidance and counseling teachers competence referred to the calculations that can be seen in the following Table 1.

Table 1

The categorization of Guidance and Counseling Teachers Competence

\begin{tabular}{|c|c|}
\hline Range of Score & Category \\
\hline $282>\mathrm{X}$ & Mastery \\
\hline $259<\mathrm{X}<282$ & Competent \\
\hline $196<\mathrm{X}<259$ & Threshold \\
\hline $158<\mathrm{X}<196$ & Flow \\
\hline $\mathrm{X}<158$ & Beginner \\
\hline
\end{tabular}

The data analysis in this study utilized the measurement method of Rasch Model by processing or analyzing all data through the utilization of the Winstep for Windows application.

\section{RESULTS AND DISCUSSION}

The general overview of Guidance and Counseling Teachers competence who attend Teacher Profession Education program in Indonesia University of Education Academic Year 2018/2019 was grouped and generally described on the following Table 2.

Table 2

Frequency Distribution of General Overview of Social Personal Competence Guidance and Counseling Teachers

\begin{tabular}{|l|c|c|}
\hline \multicolumn{1}{|c|}{ Category } & Range of Score & Frequency \\
\hline Mastery (M) & $>283$ & $1(1,5 \%)$ \\
\hline Competent (C) & $259-282$ & $46(48 \%)$ \\
\hline Threshold (T) & $197-259$ & $46(48 \%)$ \\
\hline Flow (F) & $157-196$ & $2(2.5 \%)$ \\
\hline Beginner (B) Total & $<158$ & 0 \\
\hline \multicolumn{2}{|c|}{ T5 (100\%) } \\
\hline
\end{tabular}

Based on the Table 2 above, the competence of Guidance and Counseling Teachers in the PPG- BK Program in Indonesia University of Education Academic Year 2018/2019 was in the competent category, as seen from the competent $(\mathrm{N}=46)$ and mastery $(\mathrm{N}=1)$ categories. Additionally, most of the Guidance and Counseling Teachers were also in the threshold category $(\mathrm{N}=46)$, while a few Guidance and Counseling Teachers were in the flow category $(\mathrm{N}=2)$, and there were no Guidance and Counseling Teachers in the beginner category $(\mathrm{N}=0)$. Based on the table, it can be interpreted

that most of the Guidance and Counseling Teachers in the PPG-BK Program in Indonesia University of Education Academic Year 2018/2019 have a good level of social personal competence understanding, performing a good attitude and concern for the counselee, and implement goof personal and social in providing guidance and counseling services.

Based on the data above, most of the Guidance and Counseling Teachers have been in the competent category which means that each teacher conducted his or her competence development continuously. As stated by Danim [10] to fulfill the professional criteria, the teacher must do professionalism or the process towards true professional degrees continuously in which one of them is to follow Program Pendidikan Profesi Guru Bimbingan dan Konseling (PPG- BK).

Based on data on aspects of the social personal competence of Guidance and Counseling Teachers in PPG-BK program in Indonesia University of Education Academic Yea 2018/2019, Guidance and Counseling Teachers' competencies consist of seven aspects, namely believing and devotion to Almighty God, respecting and upholding humanity values, individuality and freedom of choice, showing integrity and strong personality stability, performing high-quality performance, implementing internal collaboration in the workplace, playing a role in the organization and professional activities of guidance and counseling as well as implementing the collaboration inter professions.

Generally, the seven aspects of the Guidance and Counseling Teacher competence showed the achievement of a good competence understanding, seen from the percentage that showed the tendency of competence in competent category (C). From the Table 2, three qualified aspects (C) were obtained, namely respecting and upholding humanity values, individuality and freedom of choice, then showing integrity and strong personality stability, and performing high quality performance. The aspects in the competent category (C) means that the Guidance and Counseling Teachers had reached an optimal competence understanding.

The other four aspects, namely believing and devotion to Almighty God, implementing internal collaboration in the workplace, playing a role in the organization and professional activities of guidance and counseling, and implementing collaboration inter professions were in the threshold (T) category. The aspects in the Threshold category (C) means that the Guidance and Counseling Teachers had reached a sustainably optimal competence understanding. For more details, it is described in the Figure 1.

The Role of Guidance and Counseling Teachers can also be stated as teacher as communicator, teacher as a modernizer, and teacher as a constructor [11]. Guidance and Counseling Teachers through their duties and responsibilities as scientists must develop knowledge and foster it continuously, along with the development of science and technology. Guidance and Counseling teacher as a person, means must have a good (steady) personality or character. Guidance and Counseling teachers also have the obligation to connect schools and communities through their duties and responsibilities as a communicator. This will build the image of the Guidance and Counseling Teacher in the school as a figure that is in line with the expectations. 


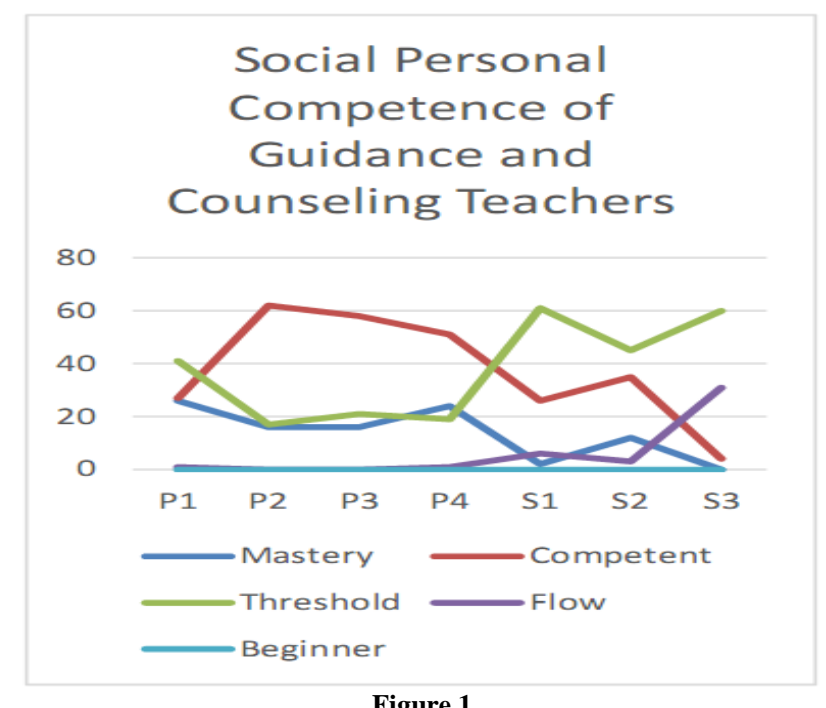

General Overview of Social Personal Competence Guidance and Counseling Teachers

\section{Description}

P1 : Aspect of believing and devotion to Almighty God.

P2 : Aspect of respecting and upholding humanity values, individuality and freedom of choice.

P3 : Aspect of showing integrity and strong personality stability.

P4 : Aspect of performing high quality performance.

51 : Aspect of implementing internal collaboration in the work place.

52 : Aspect of playing a role in the organization and professional activities of guidance and counseling.

53 : Aspect of implementing the collaboration inter professions.

The general overview of Guidance and Counseling Teachers competence who attend Teacher Profession Education program in Indonesia University of Education Academic Year 2018/2019 Grouped Based on Age, Educational Background, Tenure and Regional Background.

The general overview of the social personal competence of Guidance and Counseling Teachers in the PPG-BK Program in Indonesia University of Education Academic Year 2018/2019 grouped by age, namely Guidance and Counseling Teachers with the age range from 25-30 years old $(\mathrm{N}=34)$ were in the threshold category, the age range from $31-35$ years old $(\mathrm{N}=40)$ were in the competent category, and the age range from $36-40(\mathrm{~N}=21)$ were in the threshold category. Viewed from these data, there is an increase in the age range of 25 years to 40 years. The differences existing in age range did not limit the commitment of Guidance and Counseling Teachers to conduct their primary tasks.

Sahertian [12] teachers need to have a commitment to feel actively involved and full of responsibility that is balanced with a long effort and process. Guidance and Counseling teachers as educators, have a commitment to the tasks regardless of background. Guidance and Counseling teachers with high commitment will have a concern for the tasks, students' needs, colleagues and superiors as well as responsibilities towards the nation, state, and communities [12].

General description of Guidance and Counseling Teacher competencies based on educational background, namely Guidance and Counseling Teachers with educational background of guidance and counseling $(\mathrm{N}=$ 70) were in the competent category, whereas with nonguidance and counseling educational background $(\mathrm{N}=$ 25 ) were at threshold category. Education is the milestone of a teacher in conducting his or her obligations as an educator. Academic qualifications are needed in order to achieve suffice level of knowledge and competence to influence students positively.

As a Guidance and Counseling Teacher, four competencies are needed as a reference in the alteration and implementation of education that has been learned to be a professional teacher. One of the requirements for a teacher to be classified as professional is seen from his or her educational background [13]. It can be stated that the more appropriate between the educational background of teachers in college and the subjects taught is, the higher level of Guidance and Counseling Teachers competence is. Generally, people who have a match between the educational background and the subjects taught will have broader and commensurate insights.

General overview of Guidance and Counseling teachers' competence based on tenure, namely Guidance and Counseling Teachers with tenure under five years or referred to as new work experience $(\mathrm{N}=36)$ were in the competent category, while those with tenure under five years or called with new work experience $(\mathrm{N}=59)$ were in the threshold category. The development and improvement of the quality of the Guidance and Counseling Teacher competence are turned over to the person himself or herself with the intention that if the Guidance and Counseling Teacher is someone with great responsibility, then he or she has the drive to increase his or her capacity to be more qualified.

This was confirmed by Sagala that if the teacher really wants to develop himself or herself, then he will be qualified, because he is always searching opportunities to improve his or her own quality. As a Guidance and Counseling Teacher, the development of selfprofessionalism is demanded and conducted by all groups regardless the length of the teaching process that had been taken. Teacher professionalism development activities can be done through education and training, workshops, comparative studies, etc [14].

One thing that is being undertaken by Guidance and Counseling Teachers is the activities of the Program Pendidikan Profesi Guru Dalam Jabatan. This activity was attended by everyone from new tenure to the old ones. This description explains that every Guidance and Counseling Teacher with new or old teaching experience must always try to develop his or her competence regardless the status of his or her tenure.

The general description of Guidance and Counseling Teachers competence based on the regional background with different demographics, namely Guidance and Counseling Teachers with regional background from West Java and Banten Provinces ( $\mathrm{N}=$ 36) were in the threshold category, Guidance and Counseling Teachers with regional background from Lampung Province $(\mathrm{N}=31)$ were in the competent category, Guidance and Counseling Teachers with regional background from Bengkulu Province $(\mathrm{N}=16)$ 
were in the threshold category, while Guidance and Counseling Teachers with regional background from Riau Islands Province $(\mathrm{N}=12)$ were in the competent category.

According to Schustack [15], demographic differences in work success and professional seem to be concluded from something that is not based on personality differences. From this statement, it can be stated that demographic differences do not affect the success of someone's work, but rather affect someone's personal social life. Personalities from certain regions make it possible to have its own characteristics in someone's social life. c. Competence Improvement Program of Guidance and Counseling Teacher The competence improvement program of guidance and counseling teachers was initiated with a need assessment.

The needs assessment was conducted using a competence instrument which is a development of Minister of Education and Culture Regulations No. 27 of 2009 which has been validated and tested for reliability by using the Rasch model in order to measure the needs of guidance and counseling teachers [16]. The instrument result data was then processed to derive information about the description of the guidance and counseling teachers' competence. Then, the processed data was used as a cornerstone for designing competence improvement development programs.

The description of the needs on this program was derived from the results of competence questionnaires distribution and then the services provided include five coaching strategies, namely monitoring, consulting, training, counseling, and evaluation. The main goal of this service is to help the guidance and counseling teachers in improving their quality comprehensively and dynamically.

This improvement program for teacher and counseling teacher competence can be a reference for sustainable development in improving the quality of guidance and counseling services that makes school be independent with capacity improvement and self-quality for Guidance and Counseling Teachers who attend PPGBK Dalam Jabatan Program in Indonesia University of Education Academic Year 2018/2019.

In this research, the instrument was given only to the guidance and counseling teachers without being given to the students as the receiving object, subject teachers as objects that saw the service process took place, or the principal as the person in charge so that the competence data of the Guidance and Counseling Teacher would be more complete and trusted.

The limitations of the researcher were also based on the subject selection who were Guidance and Counseling Teachers that are currently attending the PPGBK Program in Indonesia University of Education Academic Year 2018/2019. The subjects of this research who were Guidance and Counseling Teachers from various regional backgrounds, education, age, and work experience made the researchers got difficulty to obtain an environmental assessment in the subject's teaching area.

The limited research data made the findings of Guidance and Counseling Teachers' needs not comprehensive regarding all aspects relating to personal competence, core, and supporters who should be able to become wholeness in creating programs. This program would need to be reviewed in depth both rationally and empirically so that its utilization would be more optimal in supporting the competence of the Guidance and Counseling Teacher.

\section{CONCLUSIONS}

Referring to the research problems, the research findings of the Guidance and Counseling Teacher on PPG-BK Program in Indonesia University of Education academic year 2018/2019 can be concluded as follows. 1 . Guidance and Counseling Teachers' social personal competence in general achieves good understanding based on competent categories $(\mathrm{N}=46)$ and mastery $(\mathrm{N}=1)$, meaning that Guidance and Counseling Teachers had achieved an optimal understanding of competence in the aspects of respecting and upholding humanity values, individuality and freedom of choice, then showing the integrity and stability of a strong personality, and performing high-quality performance.

The other four aspects, namely believing and devotion to Almighty God, implementing internal collaboration in the workplace, playing a role in the organization and professional activities of guidance and counseling, and implementing collaboration inter professions were in the threshold category. The aspects in the threshold category means that the Guidance and Counseling Teachers had reached a sustainably optimal competence understanding.

The Competence of Guidance and Counseling teachers based on age was in the competent category with the description of the age range of 25-30 $(\mathrm{N}=15)$, age range 31-35 $(\mathrm{N}=24)$, age range $36-40(\mathrm{~N}=7)$. It means that some Guidance and Counseling teachers with various age ranges had reached an understanding and practice of social personal competence.

The Competence of Guidance and Counseling Teachers based on educational background was in the competent category namely BK educational background $(\mathrm{N}=42)$ and Non-BK educational background $(\mathrm{N}=4)$. It indicates that some Guidance and Counseling Teachers with BK and Non-BK educational background had reached an understanding and practice of social personal competence.

The Competence of Guidance and Counseling Teachers based on tenure was in the competent category namely new tenure $(\mathrm{N}=21)$ and old tenure $(\mathrm{N}=25)$. It indicates that some Guidance and Counseling Teachers both with new tenure and old tenure had reached an understanding and practice of social personal competence.

The Competence of Guidance and Counseling teachers based on regional background was in the competent category with the description of West Java Province $(\mathrm{N}=14)$, Lampung Province $(\mathrm{N}=19)$, Bengkulu Province $(\mathrm{N}=6)$, and Kepulauan Riau Province $(\mathrm{N}=7)$. It indicates that some Guidance and Counseling teachers with various regional background had reached an understanding and practice of social personal competence.

The improvement program for Guidance and Counseling Teacher competence was formulated based on a description of the needs found in the research. This 
competence development program for BK Teachers aimed to enable BK Teachers to be able to achieve an optimal level of competence understanding.

\section{REFERENCES}

[1] Fuad, M. (2009). Kualitas pribadi konselor: Urgensi dan Pengembangannya. Jurnal Dakwah dan Komunikasi, Komunika, 3(2), 247-254.

[2] Mudjijanti, F. (2014). Pengaruh kualitas pribadi konselor terhadap efektivitas layanan konseling di sekolah. Widya Warta, (2), 260-280.

[3] Souders, E. L (2009). Counselor trainees' perceptions of their personal growth: A qualitative inquiry. Dissertation. Graduate College at ScholarWorks at WMU Western Michigan University.

[4] Rofiqah, T. (2016). Kompetensi guru bimbingan dan konseling dan upaya pembinaan. Jurnal Unrika, 1(1), 1-11.

[5] Sisrianti. (2013). Persepsi siswa tentang kompetensi kepribadian guru bimbingan dan konseling/konselor di SMPN 5 Pariaman. Jurnal Ilmiah Konseling, 2(1), 1-7.

[6] Efendi, K. (2013). Kompetensi sosial guru bk/konselor sekolah (Studi Deskriptif di SMA Negeri Padang). Jurnal Ilmiah Konseling, 2(1), 162-166.

[7] Kamaluddin, H. (2011). Bimbingan dan konseling. Jurnal Pendidikan dan Kebudayaan, 17(4), 447-454.
[8] Suherman, U. (2015). Manajemen bimbingan dan konseling. Bandung: Rizqi Press.

[9] Kusdaryani \& Fitriana. (2012). Kompetensi konselor sebagai dasar penilaian kinerja untuk meningkatkan profesionalitas guru BK. Semarang: Fakultas Ilmu Pendidikan IKIP PGRI Semarang.

[10] Danim, S. (2010). Karya tulis inovatif sebuah pengembangan profesi guru. Bandung: PT. Remaja Rosdakarya.

[11] Hamalik, O. (2003). Proses belajar mengajar. Jakarta: Bumi Aksara.

[12] Sahertian. (1994). Profil pendidik profesional. Yogyakarta: Andi Offset.

[13] Danim, S. (2002). Inovasi pendidikan dalam upaya peningkatan profesionalisme tenaga kependidikan. Bandung: Pustaka Setia.

[14] Danim, S., \& Khairil, H. (2010). Profesi kependidikan. Bandung: Alfabeta.

[15] Schustack, W. (2006). Kepribadian: Teori Klasik dan Riset Modern. Jakarta: Erlangga.

[16] Peraturan Menteri Pendidikan Nasional Republik Indonesia No. 27 Tahun 2008 tentang standar kualifikasi akademik dan kompetensi guru bimbingan dan konseling. Jakarta: Kemdiknas. 